Revista de la red interuniversitaria de estudios sobre las literaturas rioplatenses contemporáneas en Francia

$14 \mid 2016$

Levrero

\title{
Lo mejor de Tía Encarnación
}

\section{Tía Encarnación}

URL: http://journals.openedition.org/lirico/2322

DOI: $10.4000 /$ lirico.2322

ISSN: 2262-8339

Editor

Réseau interuniversitaire d'étude des littératures contemporaines du Río de la Plata

Referencia electrónica

Tía Encarnación, «Lo mejor de Tía Encarnación », Cuadernos LIRICO [En línea], 14 | 2016, Puesto en línea el 07 junio 2016, consultado el 19 abril 2019. URL : http://journals.openedition.org/lirico/2322 ; DOI : $10.4000 /$ lirico.2322

Este documento fue generado automáticamente el 19 abril 2019.

\section{(c) (1) $\Theta \Theta$}

Cuadernos LIRICO está distribuido bajo una Licencia Creative Commons Atribución-NoComercialSinDerivar 4.0 Internacional. 


\section{Lo mejor de Tía Encarnación}

\section{Tía Encarnación}

1 Lo mejor de Tía Encarnación es que por fin decidió internarse definitivamente en un cottolengo y dejarnos a todos en paz. Pero el título de esta página quería referirse a otra cosa. En efecto, sus "Consejos para la mujer y el hogar" que publicara hace algunos cuantos años la revista "Misia Dura" se dividían en dos categorías : malos y malísimos. Hoy comenzamos a publicar una selección de los malos, es decir, de lo mejor de Tía Encarnación.

2 Ese marido que usted ya no usa puede cumplir aún alguna función útil ; por ejemplo, dándole una mano de barniz, luce muy bonito en un rincón del living, como perchero ; $\mathrm{o}$, en el desván, como maniquí fuera de uso, que está tan de moda.

3 Los discos chicos de 33 revoluciones, simples o dobles, ablandándolos previamente haciéndolos hervir toda una noche, son un perfecto sustituto para la carne de las milanesas, en esta época de veda. Si encuentra que de todos modos no se pueden comer, quíteles el pan rallado y vuélvalos a escuchar en el tocadiscos : hallará algo realmente nuevo en música.

Los guisos ligeramente quemados, pierden su mal gusto tirándolos por la ventana.

5 Vertiendo en un libro de agua fría un vaso de una mezcla de éter amoniacal y alcohol por partes iguales, agregando luego una cucharada de detergente y agitando con energía la solución hasta obtener abundante espuma, podrá recoger luego la espuma en una 
esponja, para frotar no me acuerdo lo qué no con qué finalidad; era muy interesante; será en otra vuelta.

Las lapiceras a bolillas desaparecen frotándolas suavemente con alcohol fino.

7 Las manchas de frutas se limpian con cenizas. Las manchas de cenizas se limpian con fruta, y así va el mundo.

8 Si las fantasías le manchan la piel o la ropa, no estaría demás que se tomara un descanso, y de paso viera a un médico.

9 Para combatir las moscas aplique sobre éstas un algodón bien embebido en alcohol alcanforado.

El Huevo Nº, julio 1983 